\title{
Change Order Management in Nigeria: The Current Context
}

\author{
Kolawole, A. Richard (Corresponding author) \\ Department of Environmental Planning \& Mgt,Kenyatta University, Nairobi, Kenya \\ Tel: 254788158708 E-mail: rakolawole2013@gmail.com
}

Kamau, K. Peter

Department of Environmental Planning \& Mgt, Kenyatta University, Nairobi, Kenya

Munala Gerryshom

Centre for Urban Studies

Jomo Kenyatta University of Agriculture and Technology. Nairobi, Kenya

Received: July 4, 2015 Accepted: August 4, $2015 \quad$ Published: October 30, 2015

doi:10.5296/jmr.v7i5.8457 URL: http://dx.doi.org/10.5296/jmr.v7i5.8457

\begin{abstract}
In order to curb the negative impact of changes on a project, it is crucial to implement change management. This study investigated the current practice of managing change order in the Nigerian Construction Industry. A wide-ranging literature review and questionnaire survey was conducted to gain in-depth understanding of change management. Stratified random sampling was used to sample 240 respondents (including architects, quantity surveyors, building engineers and building service engineers. The Statistical Package for the Social Sciences (SPSS) version 22 was used for data analysis. The analysis results established that change management application is at $15 \%$ in Nigeria which is relatively low. Contentment with outdated methods of construction and high application cost, as well as lack of knowledge was the major drawbacks to change management. Respondent perceived benefit included faster response to change order; reduce time and human resource use. Completion schedule delay; bureaucracy-based client management, and poor coordination and documentation were the three major problems associated with construction industry practice presently. The paper concludes that based on perceived benefits attributed to change
\end{abstract}




\section{Macrothink

management, it is important that professional institutions encourage the adoption of change management through organised workshops and training.

Keywords: Benefits; Change management; Drawback; Nigeria; Construction Industry 


\section{Introduction}

Unlike manufacturing, the design and production function in construction projects are conventionally separated and are performed by different professionals or organisations working independently (Ojo,Adeyemi \& Fagbenle, 2007). This organisation characteristic of the construction industry makes construction projects complex and prone to changes or variations during the construction phase (Oladapo, 2007). The complexity of construction projects must result in change in the construction project (Oloo, Munala \& Githae, 2014). According to Ssegawa et al.,(2002) as cited in Alsuliman, Bowles \& Chen (2012) "changes in construction projects can be set off by as simple as a change of mind on the part of the project sponsor, their consultants or unanticipated issues raised by the main contractor or nominated sub-contractors". "Any additions, deletions, modification to scope, work state, process or methods that differ from the initial construction plan or specification is change" (Park, 2002). Managing project changes in Nigeria has been guided by the building contract in place for a particular building project. With the sole aim of maximising the benefit and minimizing the penalties and ensuring that both advantages and penalties are distributed reasonably. The commonly used form of a building contract is that prepared by Federal Ministry of Works and Housing. As a result, the overall change management efficacy varies per project depending on project nature, size and the level of experience of project consultants/participants. However, it is believed that with appropriate change management practice this scenario can change because preventive measures for potential changes can be planned and those changes that have already occurred can be resolved in a timely and systematic manner. This will ensure successful project execution and management and lead to more revenue for the Nigeria economy. With this argument in mind, the purpose of this paper is to investigate the current status of change management and its drawbacks as well as problems associated with current practice.

\section{Literature Review}

According to Arain \& Pheng (2005), change order at the design stage is totally unlike the construction stage. This is because the changes during the design phase do not require any rework or demolition on the construction site. This implies that, the earlier changes are rectified, the lesser negative impact it will have on the project. Furthermore, conflict over project changes can be minimized when the problem is identified at the earlier phase of the project (Hwang \& Low, 2012). This has been acknowledged in more ways than one. For instance

- Mendelsohn (1997) stated that $75 \%$ of the problems on site were generated at the design stage (as cited in Babatunde, Babalola, Jagboro \& Opawole, 2012)

- Ndihokubwayo (2008) noted that clients who spend more time and money at the design stage reduce variation orders

- Oladapo (2007) stressed that change order at the design stage leads to poor performance, whether they are owner initiated or consultant-initiated 
- According to (Arain \& Pheng, 2007) change orders are managed more easily at the earlier phases of a project, for example, during the design phase, simply because these changes do not require any rework or demolition.

If the construction world were ideal, there would be no change orders, however, in the real world change is inevitable situation in construction projects. It is therefore, not unusual for literature to focus on the testing and theorisation of how such orders can best be managed. In fact diverse strategies have been acknowledged as useful in managing change order. For over two decades, researchers have put forth theories and models on how to manage change orders (Krone, 1991; Stock \& Singh, 1999; Harrington, Conner, Horney, 2000; Gray \& Hughes, 2001; Ibbs, Wong \& Kwak, 2001). In recent times, Charoenngam et al.(2003) presented a web-based project management and a change order management system (COMS) specifically developed for coping with changes in construction projects. Standard web technologies were used and a change order procedure involving workflows roles/ actors' documents, record keeping and a centralized database were developed. Lee \& Pena-Mora (2005) used system dynamics to build dynamic project models to assist planning and control of construction projects. This dynamic projects model captured several non-value adding change iterations. The simulation is demonstrated using a case study in roads and bridges construction, and many change option policy implications were summarized based on this case study. Sun, Senaratne, Fleming, Motowa \& Yeoh (2006) designed a change management toolkit for construction projects that includes a change dependency framework, a change prediction tool, a workflow tool, and a knowledge management guide.

On their own part, Ipek \& Ömer (2007) investigated requirement-design-relationships that enable traceable requirement in architectural design. They developed a prototype system called Design Track and Used Leed requirement as a case study. Motowa, Anumba, Lee \& Pena-Mora (2007) presented some preliminary results on proactive change management through an intergrated change management system composed of an unclearlogic-based change prediction model and a system dynamics model based on the Dynamic planning and control Methodology (DPM). Similarly, Isaac \& Navon (2008) have proposed a construction change tool(CCT) which creates requirement traceability through links between client requirements and the building design. They believe that numbers of changes or the impact of changes can be controlled by capturing client requirement accurately at the beginning of the project and through the requirement traceability that is built up afterwards. Most recently Arain (2008) presented a knowledge-based decision support system (KBDSS). The system consists of two main components for selecting appropriate controls: knowledge-base and a controls selection shell. This supports management providing accurate and timely information for decision making and a user-friendly system for analyzing and selecting the control for change orders.

\section{Methodology}

Survey research design was used to conduct this study. Structured questionnaires were used as the main instrument for collecting data. The questionnaires were used to elicit opinions from core construction professionals namely: architects, quantity surveyors, building 
engineers and building service engineers. The questionnaires were divided into three parts. The first part requested the respondent's profile, and the second and last parts consisted of questions that focused on obstacles and perceived advantages of having a change order management system. A stratified random sampling procedure was engaged to obtain the required sample size of the population in the Nigerian construction industry. The choice of public building is informed by the fact that "government share in the construction industry is above 75 percent of the construction sector" (Omole, 2000.P21). A total of 240 questionnaires were administered out of which 214 were returned representing a $90 \%$ response rate, which is above the recommendation by Naou, (2007) for a structured questionnaire survey. It also compares well with the $95 \%$ response rate of Toor \& Ogunlana (2008). The Statistical Package for Social Science (SPSS) Version 22 was used to run descriptive analysis correlation and reliability tests.

\section{Result and Discussion}

\section{Change Management Status}

The findings of this study show that there is currently no formalised change management system in the Nigerian construction industry. The findings reveal that $15 \%$ of respondents claimed they knew a fair amount about change management system, while $85 \%$ claimed that they knew nothing about change management. Further enquiry indicates that current practice is based on valuation of change order approach provided in building contracts. According to Ramus, Birchall, \& Griffiths ( 2006), it involves:

(i) Identifying the change order (Architect Instruction)

(ii) Evaluating and valuing of change order

(iii) Approving and documenting

(iv) Implementing change order by contractor

This finding is in line with the study of Olateju, Abdul-Azeez \& Alamutu (2012) that discovered that project management tools and techniques are still not well implemented in most public agencies in Nigeria. Change management is one of the project management practices that help in problem solving when change occurs in a project and it also helps reduce change effect that may occur and disturb the project moving ahead (Zhao, Lv,Zuo \& Zillante (2009).

\section{Drawbacks to Change Management Application}

In Table 2, the drawbacks to the application of change management in public agencies were analysed. 
Table 2. Drawbacks to Change Management Application

\begin{tabular}{lll}
\hline Factors & Mean & Rank \\
\hline Contentment with current method & 4.12 & 1 \\
\hline High application cost & 4.11 & 2 \\
\hline Lack of knowledge & 4.08 & 3 \\
\hline People refusing to learn & 4.00 & 4 \\
\hline Lack of sufficient contracts & 3.93 & 5 \\
\hline Lack of awareness & 3.89 & 6 \\
\hline
\end{tabular}

As shown, the crucial obstacle is contentment with the current method; high application cost and lack of knowledge. These finding are in line with Olateju et al., (2011) who identified lack of in-depth knowledge of project management and high application cost as obstacles to implementing PM tools and techniques by public institutions in Nigeria. In Singapore Hwang \& Low (2012) identified that being comfortable with a particular method as one of the barriers to change management by construction companies. Changing a process requires both human resources and technical requirements to support it and all these require some monetary investment. Respondents revealed therefore that staff prefers to remain with methods they are used to than make a change.

\section{Perceived Benefits of Change Management}

Perceived benefit of employing change order management were examined in Table 3.

Table 3. Perceived Benefits of Change Management

\begin{tabular}{lll}
\hline Factors & Mean & Rank \\
\hline Fast response to change & 4.24 & 1 \\
\hline Reduced time & 4.15 & 2 \\
\hline Reduced human resource requirements & 3.78 & 3 \\
\hline Cost saving & 3.67 & 4 \\
\hline Project risk improvement & 3.16 & 5 \\
\hline
\end{tabular}


All respondents agreed that good change management would lead to a faster response to change order. Other benefits of good change management include: reduced time taken and human resources spent on a project. This further supports the importance of change management. This finding is in line with those of Hwang \& Low (2012); Motowa et al., (2007) and Olateju et al., (2011) who noted that the application of project management tools and techniques improves processes.

\section{Current Problems Associated with Current Practice}

Table 4 shows what was considered problems associated with the current practice in building construction.

Table 4. Current Problems Associated with Current Practice

\begin{tabular}{lll}
\hline Factors & Mean & Rank \\
\hline Completion schedule delays & 4.38 & 1 \\
\hline Bureaucracy of client & 4.37 & 2 \\
\hline Poor coordination \& documentation & 4.22 & 3 \\
\hline Late design change & 4.00 & 4 \\
\hline Delay in the procurement process & 3.64 & 5 \\
\hline
\end{tabular}

The respondents were presented with five (5) options and were asked to indicate which of these options affected the managing of change orders the most. Table 4 indicates that delays in the procurement process, completion schedule delay, and bureaucracy in public institution in effecting change were the three major problems associated with the current practice. This finding compares with that of Alsuliman et al., (2012) who also found that bureaucracy of public client was one of the problems associated with variation management in Saudi Arabia. Documentation of a change is said to be a vital element in any change management system and the lack of it can jeopardize the right of a contractor to collect fair compensation for a change (Al-Dubaisi, 2000).

\section{Implication of Findings}

The implication of this finding is that the Nigerian construction industry does not enjoy the advantages of change management processes which include: reduction in processing cost, reduced timelines, standardization of methods of managing change orders, streamlining steps of managing change order easier, proper documentation, and a decline in error rates.

\section{Recommendations}

Based on the findings on perceived benefits, it is recommended that the Nigerian construction industry needs to embrace change management. Additionally, since every evolution in 
expertise in this century has being accomplished with advances in computer science, embracing change management can be achieved by

(i) The federal government needs to use change management software on all projects. This software should be one that is easy to configure, easily incorporated with other systems and provides a high level of computerization without encumbering users.

(ii) Different professional institution need to organize workshop and training courses on change management processes.

(iii) Undergraduate Contract Administration curricula should include change management at for all building construction students.

\section{Conclusion}

This paper set out to investigate the current management status of change management in Nigeria and to explore the obstacles and advantages of implementing change order management.

Based on the result of this study, change management in Nigeria is relatively low. Contentment with current methods and high application cost, as well as lack of knowledge were the major drawbacks to change management. Respondent perceived that advantages of change order management included: faster response to change order; reduce time spent and reduce human resource required. While completion schedule delay; bureaucracy in public institution and poor coordination and documentation were the three major problems associated with the current practice.

\section{References}

Al-Dubaisi, A. (2000). Change Order in Construction Project in Saudi Arabia, Msc Thesis, Faculty of the College of Graduate Studies. Saudi Arabia: King Fahd University of Petroluem $\&$

Minerals. http://faculty.kfupm.edu.sa/cem/assaf/students_reports/change-orders-in-construction.pdf

J. Alsuliman J, G. Bowles, G, \& Chen, Z, (2012). Current Practice of Variation Order Management in Saudi construction industry. In 28th Annual ARCOM Conference Edinburgh: Smith,S.D Ed $\quad$ pp. 1003-1012. http://www.arcom.ac.uk/-docs/proceedings/ar2012-1003-1012_Alsuliman_Bowles_Chen.pdf

Ameh, J., \& Odusami, K. (2010). Nigerian Building Professionals' Ethical Ideology and Perceived Ethical Judgement. Australian Journal of Construction Economics and Building, 10(3), 1-13http://dx.doi.org/10.5130/AJCEB.v10i3.1602

Arain, F., \& Pheng, L. (2006). Effective Management of Contract Variations using Knowledge Based Decision Support Systems. Cadiff: Centre for Education in the Built Environment. ISBN13 9781905148097 
Arain, F., \& Pheng, L. (2007).Modelling for Management of Variation in Building Projects. Engineering Construction and Architectural Management, 14(5), 420-433 http://dx.doi.org/10.1108/09699980710780737

Babatunde, S. O., Babalola, O., Jagboro, G. O., \& Opawole, A. (2012). An Assessment of Building Elements' Proneness to Variation in Nigerian. Journal of Construction Project Management and Innovation 2(2), 424-447. http://reference.sabinet.co.za/webx/access/electronic_journals/jcpmi/jcpmi_v2_n2_a7.pdf

Charoenngam, C., Coquinco, S. T., \& Hadikusumo, B. W. (2003). Web-based application for managing change orders in construction projects. Journal of Construction Innovation, 197-215.

Gray, C., \& Hughes, W. (2001). Building Design Management. Oxford, UK: Butterworth-Heinenmann.

Harrington, H. J., Conner, D. R., \& Horney, N. L. (2000). Project Change Management. New York: McGraw Hill.

Hwang, B. G., \& Low, L. K.(2012). Construction project change management in Singapore: Status, importantce and impact. International Journal of Project Management, 30, 817-826. http://dx.doi.org/10.1016/j.ijproman.2011.11.001

Ibbs, C., Womg, C., \& Kwak, Y. (2001). Project Change Management System. Journal of Management in Engineering ASCE, 17(3), 159-165. http://home.gwu.edu/ kwak/PCMS.pdf

Isaac, S., \& Navon, R. (2008). Feasibility study of an automated tool for identifying the implication of changes in construction projects. Journal of Construction Engineering \& Management 134(2), 139-145. http://dx.doi.org/10.1061/(ASCE)0733-9364(2008)134:2(139)

Lee, S. H., \& Pena-Mora, F,. (2005).System dynamics approach for error and change management in concurrent design andconstruction. Summer Simulation Conference, (pp. 1508-1514). Orlando Florida http://dx.doi.org/10.1109/WSC.2005.1574418

Motowa, I. A., Anumba, C. J., Lee, S., \& Pena-Mora, F., (2007). An Intergrated system for change management in construction. Journal of Automation in Construction, 368-377. http://dx.doi.org/10.1016/j.autcon.2006.07.005

Nauom, S. (2007). Dissertation Research and Writing for Construction Students. London: Reed Education \& Professional Publishing Ltd, Butterworth-Heinemann.

Ndihokubwayo, R., \& Haupt, T. (2009). VariationOrders on Construction Project Value Adding or Waste? International Journal of Construction Project Mangement, 1(2), 1-17 http://works.bepress.com/ruben_ndihokubwayo/11

Ogwueleka, A. (2011). The Critical Success Factors Influencing Project Performance in Nigeria. International Journal of Management Science and Engineering Management 6(5), 343-349. http://dx.doi.org/10.1080/17509653.2011.10671182 


\section{Macrothink}

Journal of Management Research

ISSN 1941-899X

2015, Vol. 7, No. 5

Ojo, S. O., Adeyemi, A. Y., \& Fagbenle, O. I. (2007). The Performance of Traditional Contract Procurement on Housing Projects in Nigeria. Dimensi Teknik Sipil, 9(1), 81-85 (2011). http://puslit.petra.ac.id/journals/civil

Oladapo, A.A. (2007). Quantitative Assessment of the Cost and Time Impact of Variation Orders on Construction Projects. Journal of Engineering, Design and Technology 5(1), 35-48. http://dx.doi.org/10.1108/17260530710746597

Olateju, O. I., Abdul-Azeez, I. A., \& Alamutu, S. A. (2011) Project Management Practice in Nigerian Public Sector-An Empirical Study. Australian Journal of Bussiness and Management Research,1(8), 1-7 http://www.ajbmr.com/articlepdf/AJBMR_17_26i1n8a1.pdf.

Oloo, D., Munala, G., \& Githae, W. (2014). Factors Contributing to Variation Orders: A survey of Civil Engineering Construction Projects in Kenya. International Journal of Social Science $\quad$ and $\quad$ Entrepreneurship 1(12), http://www.ijsse.org/articles/ijsse_v1_i13_425_437.pdf

Omole, O., Framework for a Code of Procedure for Open and Competitive Tendering : NIQS Open and Competitive Tendering in the Procurement of Public and Private Sector Projects. Lagos: Irede Printers Limited 129p(2000).

Park, M. Dynamic Change Management for Fast-tracking Construction. Retrieved October 25, 2013, from Building and Fire Research Laboratory(2002): http://fire.nist.gov/bfrlpubs/build02/art129.html

Stocks, S., \& Singh, A. (1999). Studies on the impact of functional analysis concept design on reduction in change orders. Construction Management and Economics, 17, 251-267. http://dx.doi.org/10.1080/014461999371475

Sun, M., Senattena, S., Fleming, A., Motowa, I., \& Yeoh, M. (2006). A change menagement toolkit for construction projects. Architectural Engineering and Design Management, 2(4), 261- 271. http://dx.doi.org/10.1080/17452007.2006.9684621

Toor, S. R., \& Ogunlana, S. O. (2008). Construction professionals' perception of critical success factors for Large-Scale construction projects. Journal of Construction Innovation 9(2), 149-167 http://www.emeraldinsight.com/doi/abs/10.1108/14714170910950803

Zhao, Z. Y., Lv, Q. L., Zuo, J., \& Zillante, G. A. (2009). Prediction System for Change Management in Construction Project. Journal of Construction Engineering and Management 136(6), 659-669. http://dx.doi.org/10.1061/(ASCE)CO.1943-7862.0000168. 